\title{
Does Participation in Agricultural Value Chain Activities Influence Smallholder Fruit Grower Production Performance? A Cross-Sectional Study of Apple Farmers in Shandong, China
}

\author{
Xiaolei Wang ${ }^{1,+}$, Apurbo Sarkar ${ }^{2,+}$, Hongyu Wang ${ }^{2}$ and Fuhong Zhang ${ }^{3, *(\mathbb{D}}$ \\ 1 College of Information Science and Engineering, Shandong Agricultural University, Tai'an 271018, China; \\ 2018110568@sdau.edu.cn \\ 2 College of Economics \& Management, Northwest A\&F University, Yangling 712100, China; \\ apurbo@nwafu.edu.cn (A.S.); wanghongyu@nwafu.edu.cn (H.W.) \\ 3 College of Economics and Management, Shandong Agricultural University, Tai'an 271018, China \\ * Correspondence: sdzhangfuhong@sdau.edu.cn \\ + These authors equally contributed to the work.
}

check for

updates

Citation: Wang, X.; Sarkar, A.; Wang, H.; Zhang, F. Does Participation in Agricultural Value Chain Activities Influence Smallholder Fruit Grower Production Performance? A Cross-Sectional Study of Apple Farmers in Shandong, China. Horticulturae 2021, 7, 153. https:// doi.org/10.3390/horticulturae7060153

Academic Editor: Elazar Fallik

Received: 29 April 2021

Accepted: 9 June 2021

Published: 15 June 2021

Publisher's Note: MDPI stays neutral with regard to jurisdictional claims in published maps and institutional affiliations.

Copyright: (c) 2021 by the authors. Licensee MDPI, Basel, Switzerland. This article is an open access article distributed under the terms and conditions of the Creative Commons Attribution (CC BY) license (https:// creativecommons.org/licenses/by/ $4.0 /)$.

\begin{abstract}
The value chain comprises several factors and activities useful for strengthening production and distribution by connecting producers with suppliers, intermediaries, and marketplaces and collaboratively creating added value for products or goods. However, the values of agricultural products mostly depend on various factors and actors, which should be linked together for fostering added values. Thus, there may be strong ground for facilitating a smooth transition of the agricultural value chain (AVC) within the prospects of emerging countries. It could be a key means of promoting a profound connection between smallholder farmers and modern agriculture facilities. It could be especially crucial for the highly perishable and high-value product such as fruits. The main aims of the study are to evaluate the factors influencing smallholder apple farmers' participation in the agricultural value chain and determine whether participation in AVC improves farmers' production performance. The empirical setup of the study was chosen based on survey data of apple growers in Shandong, China. The propensity score matching (PSM) and inverse probability weighted regression adjustment (IPWRA) models were employed to craft the study's outcomes. The main conclusions are as follows. (1) Fruit farmers' gender, total household expenditure, housing value, planting scale, planting years, degree of specialization, days of family labour input, and total days of employment have significant effects on their participation in AVC activities. (2) Fruit farmers' usage of improved fertilizers and organization participation supports a higher yield and net income per acre. (3) Participating in two kinds of AVC can significantly improve the yield per acre and net income per acre compared with only using one type of AVC (improved fertilizer). Policy makers should improve the existing policy by eliminating institutional barriers and enhancing human factors for farmers to participate in high-value chain activities. Governments should extend technical support, and enhance training facilities, and comprehensively promote the AVC among smallholder farmers. Finally, farmers' organizations (e.g., cooperatives and credit organizations) should come forward to help facilitate the effectiveness of AVC.
\end{abstract}

Keywords: smallholder farmers; value chain integration; apple industry; production performance; improve fertilizer use

\section{Introduction}

Agriculture can be considered both a profession and a socioeconomic branch, which quantifies any country's gross domestic product (GDP) and rectifies any country's conditions of maintaining food security, health, nutrition, and social well-being [1-3]. Agriculture also fosters all developmental aspects, including the efficiency of production, ecology, and sustainable growth [4]. It eventually constitutes a prime concern for maintaining viable 
and comprehensive natural resource utilization within the aspects of water, land, and biodiversity [5-7]. However, in reality, agriculture seems to be a perilous endeavour. The staggering impacts of global warming and climate changes also pose a greater burden for the agrarian sector and make it riskier [8-10]. Growing detritions of land, water, and other natural resources further create ample problems for maintaining profound growth in these crucial sectors. It is essential to reshape the agrarian structures to support the current society in terms of economic, social, and environmental sustainability when the global ecosystems have become more frazzled. The global agricultural transition will require substantial efforts to satisfy the ever-increasing food requirements for the expanding population [11,12]. In these circumstances, the smallholders are going to be sufferers as their livelihood depends on agriculture. Small-scale farming is one of the largest economic sectors, solely responsible for the primary income source and livelihood for $96 \%$ of the global agricultural population [13-15]. However, diversifying in accumulating capital intensity and financial output trends are key factors for maintaining socioeconomic well-being and fostering sustainability. Therefore, nearly every individual, particularly smallholder growers, tend to be connected with markets within the aspects of broader agricultural economies [16]. The nearest market is a crucial option for smallholders in the rural region to acquire necessary agricultural inputs such as seedling, fertilizers, and mercenaries or to rent additional farming facilities [17-19]. Simultaneously, rural agro-product mostly goes into local markets, and numerous rural inhabitants are also interconnected within markets as agricultural labourers [20-22]. It is evident that smallholders' production efficiency must be raised to satisfy the growing demands of nutritious foods, fibre, and other agricultural materials and upholds sustainable transition in a broader sense [1,23,24]. Smallholders' efficiency-boosting is tactical. However, if smallholders' market links are not reinforced, such tactics will diminish their effectiveness $[20,25,26]$. Simultaneously, smallholder farmers largely involve several distinct features and confront numerous challenges to their potential contributions in facilitating livelihood development and reducing poverty [27-29]. Therefore, there is a profound ground for the agricultural value chain (AVC) facilities to foster efficiency and eventually boost the income-increasing capabilities of smallholder farmers.

According to the Ministry of Agriculture and Rural Affairs' forecast, $80 \%$ of China's total cultivated area will still be managed by 220 million small farmers by 2020 , and the average planting scale will still be less than 8.2368 acres. Therefore, small farmers are the most fundamental production unit in China's agriculture at the current stage. In September 2018, the State Council deliberated and passed the policies regarding "Opinions on Promoting the Organic Connection between Small Farmers and Modern Agriculture". Moreover, it proposed a long-term innervation to accelerate the basic connection between small farmers and modern agriculture and improve their production and operation capabilities [30,31]. It is gratifying to note that small farmers have realized the importance of agricultural science and technology and are increasingly accepting the supports of professional training, production and unified sales supported by professional organizations [32,33]. Those are widely integrated into the modern agricultural value chain through various combined modes such as "farmers plus cooperatives", "contract farming plus enterprises", and so on $[34,35]$. By promoting the integration of small farmers into the value chain of modern agriculture, it is helpful to solve the contradictions between small-scale decentralized management and large-scale socialized production of farmers [36,37] and comprehensively improve the international competitiveness of agriculture [38-40]. Therefore, they can reduce production costs and transaction costs [41-43], promote the connection between production and marketing, enter differentiated market segments, and highlight value appreciation [44-46]. In addition, the organization promotes the integration of farmers into the industrial chain at every stage before, during, and after production by formulating production standards and implementing standard and brand-based management [47-49], thereby providing the market with agricultural products that meet consumer demand and quality and safety standards, reducing farmers' sales risk and improving farmers' produc- 
tion performance [50-53]. Although there has been a rising concern with the integration of farmers' into the industrial chain, the research on its impact on farmers' production performance is relatively rare. The root of such an issue may arise as it is difficult to measure the specific forms and extent of farmers' participation in the agricultural value chain [54-56]. However, the prime aim of the study is to empirically assess the impacts of smallholder fruit growers' participation in agricultural value chain activities for fostering production performance. The article's prime innovations are as follows. (i) The study analyzes the mechanism that can quantify the impacts of farmers' integration into the agricultural value chain to improve their production performance from the perspective of resource endowment. (ii) We conduct an empirical analysis to identify the factors that influence farmers' decision to integrate into the value chain facilities. We use a combination of the PSM and IPWRA models to quantitatively analyze the impact of different degrees of the agricultural value chain on production performance. To the best of our knowledge, the study will be one of the first attempts to use a combined PSM and IPWRA model approach for measuring the impacts of smallholder farmers' participation by means of their production performance.

\section{Research Design and Hypothesis Setup}

\subsection{Concept Definition}

In a report published in 2005, the Food and Agricultural Organization in the United Nations (FAO) defines agricultural value chain as the combination of institutions and set of activities that assist the farmers to bring agricultural products from farm to final consumption and add value to them at each stage [57,58]. Several recent studies highlighted that the integration of farmers into the agricultural value chain helps achieve higher returns [59-62]. This paper chose apples as the research object of agricultural value chain mainly based on the following three considerations. First, the degree of commercialization of apples is high; more than $90 \%$ of the apples produced by fruit farmers are sold in the form of daily commodities. Second, the apple industry chain is relatively long. As a premier high-value agricultural product, the apple value chain involves a variety of links such as production, purchase, processing, storage, transportation, wholesale, and retail. On the other hand, the harvesting season of apples is relatively concentrated, but the market sales need to be based on the market supply and demand, and the apples need to be put out of the market in batches. Third, in China, the apple market is relatively competitive, the price of apple market fluctuates greatly, the fruit farmers are more sensitive to market price, and the operation risk is also relatively high. The above production and operation characteristics create necessary conditions for farmers to integrate into the agricultural value chain. In the production and marketing process, the integration of fruit farmers into the value chain is mainly reflected in the following three aspects: (i) the use of factors of production provided by industrial organizations, such as applying specific fertilizers provided by the organizations; (ii) organizing fruit farmers to participate in specialized technical training; and (iii) the unified purchase and sale of apples by the industrial organizations during the harvest season. In the context of the study, we choose apple production as the research object.

Apple is a kind of agricultural product with high value, and its value chain involves a variety of links such as production, purchase, processing, storage, transportation, wholesale, and retail. Therefore, it is viable to study the impacts of value chain participation within the aspects of apple producers.

\subsection{The Influence Mechanism of the Value Chain on Apple Farmers' Production Performance}

Figure 1 portrays the impact mechanism of the influence of farmers' participation in the industrial chain on their performance. The mechanism of apple farmers' integration into the value chain on their production performance is as follows. (i) The agricultural value chain has been formed by integrating the value chain and the prospects of industrial organization. While participating in the agricultural value chain will establish a relatively stable 
contractual relationship with relevant industrial organizations [34,63,64], industrial organizations essentially help farmers by providing continuous supports to ensure the quality and safety of agricultural products. This also helps farmers optimize land allocation efficiency and improve their production and operation efficiency and performance $[31,65,66]$. The value chain's key functions are reducing the cost of inputs and improving farmers' efficiency and production performance [67-69]. (ii) Farmers' integration into the value chain is also a process of organic connection with modern agriculture [70,71]. To improve the quality of agricultural products, industrial organizations will provide specialized technical training for farmers to reduce the market risk caused by production uncertainty [16,31]. In contrast, the improved agricultural product's quality and the reduction of market risk are the sources of continuous operating income and the guarantee of increasing value in the value chain $[72,73]$. (iii) When farmers integrate into the agricultural value chain, they will form various commercial organizations and operation modes [74,75]. The initiative is beneficial to the re-integration of agricultural resources and the provision of agricultural social services, forming cooperative effects among them and promoting the continuous appreciation of the industrial value chain by reducing market access limitations and transaction costs $[53,76,77]$. Due to their limited resource endowment and capability, small farmers cannot increase the value of agricultural products through value chain activities such as processing of agricultural products and brand building [78,79]. Through participating in value chain activities such as unified purchases and sales by industrial organizations, farmers can reduce transaction costs and market risks. In addition, to a certain extent, the brand effect of products can be realized by participating in the unified acquisition of industrial organizations, and the value-added of agricultural products brought about by the marketing link of the industrial chain can be obtained with the help of the negotiation ability of industrial organizations $[80,81]$ to increase the production performance of farmers in the unit planting area (Figure 1). After comprising the above points, the paper proposes the following hypotheses:

H1. Fruit farmers using the improved fertilizer uniformly provided by the industrial organizations have a higher yield per acre and net income per acre of apples than those who do not.

H2. Fruit farmers who participated in the specialized technical training and guidance provided by the organizations have a higher yield per acre of apples than those who did not.

H3. Compared with the mode of market transaction, farmers participating in unified purchases by industrial organizations can improve their net income per acre.

Provide production factors

(improvement inputs)

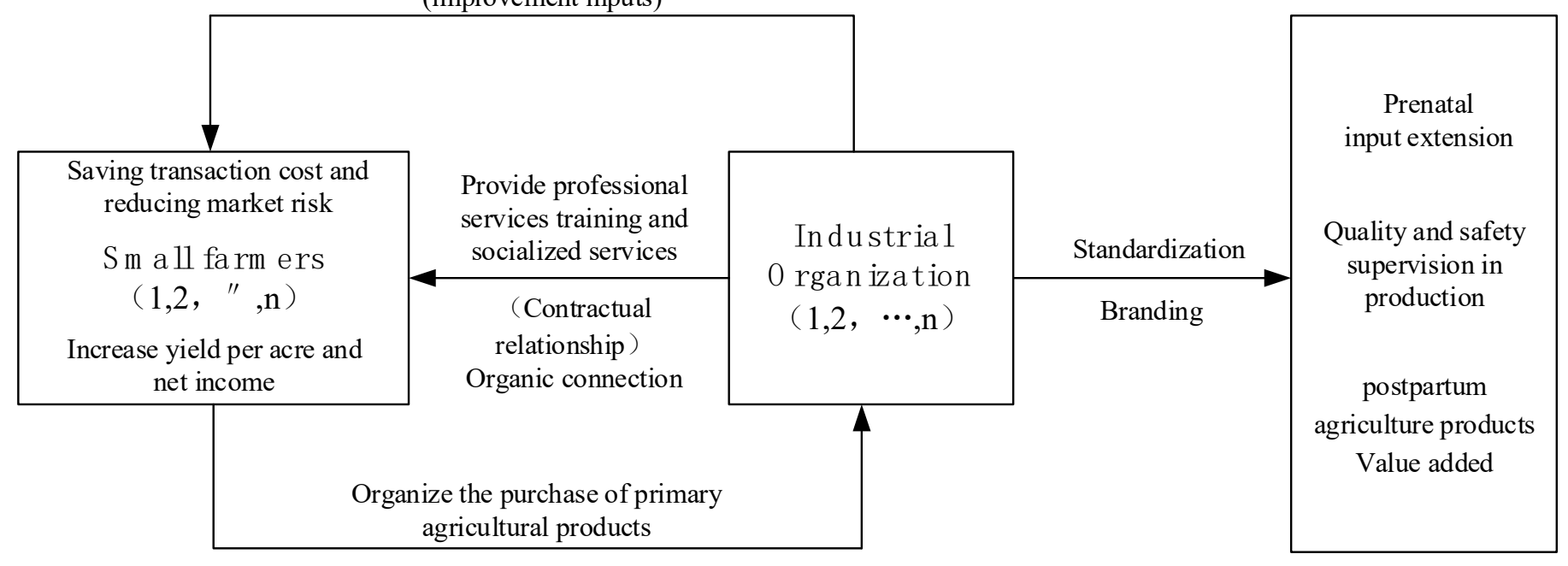

Figure 1. Mechanism of the influence of farmers' participation in the industrial chain on their performance (original). 


\section{Data Source, Variable Selection, and Research Method}

\subsection{Data Source and Variable Selection}

\subsubsection{Data Source}

Along with the superior resources and service outlets of the National Engineering Research Center for Apple of Shandong Agricultural University, a well-trained research team consisting of five master's students and three $\mathrm{PhD}$ students from the school of economics and management conducted targeted research on the main apple-producing areas in Shandong Province from July to August in 2019. In this survey, the local village cadres and cooperatives were contacted through the agricultural technology extension stations set up by local agricultural bureaus, who organized relevant apple growers to participate in the questionnaire survey. The survey was carried out in two stages. In the first stage, a pre-survey was conducted within randomly aligned six apple farmers from Guanshui Town in Muping District of Yantai City and Shiliang Town in Longkou City and then the questionnaire was modified. In the second stage, the research team purposely selected the areas with concentrated apple planting for the survey, covering the nine largest apple planting counties (cities) under the jurisdiction of Yantai, Zibo, and Linyi. The survey adopts a combined method of PPS sampling and simple random sampling. First, seven sample towns were selected from each county (city, district), and then four sample villages were selected from each town. Finally, two fruit farmers were randomly selected from each sample village as the sample farmers, and the householder or family members mainly engaged in apple planting (when the householder goes out) were selected as the respondents. In order to ensure the quality of the sample, the measures adopted in this study include face-to-face interviews with apple farming households and other relevant subjects by investigators. In order to encourage interviewers to participate in the interviews, the research team provided the respondents with a token of $\$ 1.43$ and some small gifts so that the probability of interviewers refusing to interview was low. However, they were informed that they could opt out any time during the interview period. A total of 510 questionnaires were distributed, and 475 were recovered, with an effective rate of $93.14 \%$.

\subsubsection{Variable Selection}

This paper considers the participation and extent of fruit farmers in various value chain activities as the dependent variable. For example, when the fruit farmers participate in any value chain activity, the value is 1 ; otherwise, it is 0 . Moreover, their influence on fruit farmers' production performance is analyzed. The yield per acre and the net income per acre were selected as the outcome variables. The respondents' basic characteristics and production and operation characteristics were selected as the main control variables suggested by existing literature. Table 1 shows the meaning and descriptive statistics of the dependent variables, control variables, and result variables.

Table 1. Definition and descriptive statistics of variables.

\begin{tabular}{|c|c|c|c|}
\hline Variable & Definition and Assignment & Mean & SD \\
\hline \multicolumn{4}{|l|}{ Independent variables } \\
\hline Whether to use improved fertilizer (INPUT) & $\begin{array}{l}\text { "Do you use the improved fertilizer uniformly provided by } \\
\text { the industrial organizations?" No }=0 ; \text { Yes }=1\end{array}$ & 0.4400 & 0.4970 \\
\hline $\begin{array}{l}\text { Whether to participate in the purchase by the } \\
\text { organization (PURCHASE) }\end{array}$ & $\begin{array}{l}\text { "Do you participate in the unified purchase by the } \\
\text { industrial organization?" No }=0 ; \text { Yes }=1\end{array}$ & 0.6610 & 0.4730 \\
\hline $\begin{array}{l}\text { Whether to participate in the specialized training } \\
\text { provided by the industrial organization } \\
\text { (TRAINING) }\end{array}$ & $\begin{array}{l}\text { "Do you participate in the specialized training provided by } \\
\text { the industrial organization?" No }=0 ; \text { Yes }=1\end{array}$ & 0.7620 & 0.4730 \\
\hline \multicolumn{4}{|l|}{ Control variables } \\
\hline Basic characteristics of the respondent & & & \\
\hline
\end{tabular}


Table 1. Cont.

\begin{tabular}{|c|c|c|c|}
\hline Variable & Definition and Assignment & Mean & SD \\
\hline Gender (GEN) & Female $=0 ;$ Male $=1$ & 0.3690 & 0.4830 \\
\hline Age (AGE) & Age of the respondent by 2019 (one full year of life) & 55.9850 & 11.1380 \\
\hline Degree of education (EDU) & Education years of the respondent (years) & 7.9710 & 3.2230 \\
\hline Total household expenditure (FAMC) & Annual total household expenditure of the respondent (\$) & $\$ 5451.5447$ & $\$ 4081.7076$ \\
\hline Distance from the county government (DIST) & Distance from the county government $(\mathrm{km})$ & 28.9310 & 19.2550 \\
\hline Housing value (FWJ) & The average estimated value of the house (\$) & $\$ 19,242.5376$ & $\$ 12,970.0614$ \\
\hline \multicolumn{4}{|l|}{ Characteristics of production and operation } \\
\hline Planting scale (AREA) & The average planting area of apples in 2019 & 5.6000 & 2.7020 \\
\hline Planting year (YEARS) & The actual number of years of apple planting & 22.3500 & 6.2540 \\
\hline Whether to participate in cooperatives (COOP) & $0=$ Yes $;$ No $=$ No & 0.1990 & 0.4010 \\
\hline Degree of specialization (SPDE) & $\begin{array}{l}\text { The proportion of income from apple production in total } \\
\text { household income in } 2019(\%)\end{array}$ & 77.3630 & 4.2280 \\
\hline Out-migration for work (OUT) & "Have you ever or recently gone out to work?" No = 0; Yes = 1 & 0.6070 & 0.4880 \\
\hline Number of days of family labour input (JR) & Number of days of family labour input in apple planting & 619.1030 & 299.3790 \\
\hline Days of employment (GR) & Days of labour input except for family members & 18.0590 & 50.1740 \\
\hline $\begin{array}{l}\text { Whether there is a freeze-up disaster in three years } \\
\text { (DZAI) }\end{array}$ & $\begin{array}{l}\text { "Whether the orchard suffered from freeze-up disasters in } \\
\text { recent three years?" No = 0; Yes = } 1\end{array}$ & 0.9280 & 0.2580 \\
\hline \multicolumn{4}{|l|}{ Outcome variables } \\
\hline Yield per acre (PMOV) & The gross sales income of apple in 2019 (kg/acre) & 3332.1397 & $10,053.8070$ \\
\hline Net income per acre (PMNI) & The sales income of apple minus the input cost in 2019 (\$/acre) & $\$ 5474.6586$ & $\$ 347.7048$ \\
\hline
\end{tabular}

\subsection{Research Methods}

\subsubsection{Propensity Score Matching (PSM) Model}

PSM is a non-parametric method that is feasible and rational in solving selection bias [82,83]. The basic principle of the PSM model is as follows: (i) according to the counterfactual causal inference analysis framework, the polytomy variables are converted into propensity score values, and (ii) the treatment group and the control group are matched according to such propensity score values so that the main characteristics of the control group and the treatment group remain similar $[84,85]$. Moreover, the data of the control group are used to simulate the state results of the treatment group when it is not interfered with by the (counterfactual) experiment, and then the average treatment effect (ATT) after sample interference is estimated [86]. This paper estimates the impact of three value chain activities of fruit farmers on their production performance. The difference between participating fruit farmers and non-participating fruit farmers in yield per acre and net income per acre is compared and carefully analyzed. The PSM model is implemented in the following three steps:

Step 1: The Probit model is first used to estimate the propensity scores of four different treatment methods. For each treatment method, the Probit model specifies as follows.

First, the Probit model is used to estimate the conditional probability fitting value, i.e., the propensity score value (PS value), of a group of households participating in value chain activities under the condition of a given endowment characteristic $X_{i}$ :

$$
I=\beta_{0}+\beta_{1} X+\varepsilon
$$

where $I$ is the binary choice variables of whether fruit farmers participate in value chain activities, $X$ is a group of family and production and operation variables related to the decision of participating in value chain activities, $\beta$ is the vector of the coefficient to be estimated, and $\varepsilon$ is a stochastic error term affecting value chain activities. Moreover, the 
three Probit models corresponding to these three value chain activities all use the same set of explanatory variables $[87,88]$.

Step 2: According to the similar propensity scores, the experimental group is paired with the control group. A combination of four methods (nearest-neighbour matching, caliper matching, kernel matching, and radius matching) is used to calculate the average treatment effect and ensure the results' robustness.

Step 3: The following equation calculates the average treatment effect (ATT) of value chain activities on fruit farmers' production performance:

$$
\mathrm{ATT}=E_{(P(X) \mid I=1)}\{E[Y(1) \mid I=1, P(X)]-E[Y(0) \mid I=0, P(X)]\}
$$

where $Y(1)$ and $Y(0)$ are the results of the experimental group and the control group, respectively; and the explained variable is measured by yield per acre and net income per acre, with $I=1$ for the experimental group and $I=0$ for the control group.

\subsubsection{IPWRA Model}

The multivalued intervention effect refers to that each subject can accept zero, one, or several different interventions for comparative analysis of effects after intervention. Thus, it is judged whether participating in agricultural value chain activities has significant influence on fruit farmers' production performance. The paper uses the PSM and IPWR models to analyze the impact of agricultural value chain on production performance quantitatively, which is the innovation of this paper. According to the literature on multi-value treatment, e.g., Lechner [89] and Kissoly et al. [90], this paper evaluates the participation of fruit farmers in one or more value chain activities that significantly affect their production performance. IPWRA is a statistical technique for calculating statistics standardized to a pseudo-population different from that in which the data were collected. The IPWRA model combines the method of regression adjustment (RA) and the method of inverse probability weighted (IPW) [91]. This combines the characteristics of the outcome model and the intervention state model, and uses the reciprocal of the intervention probability weight to estimate the missing data correction regression coefficient and if any one of the outcome equation model or intervention equation model is set correctly, then consistent estimation results can be obtained [92,93]. The IPWRA model can specify intervention variables for multiple pre-processing. The advantage of this model is that it is different from the general matching model and it will make the regression result more robust [94]; its results are doubly robust $[95,96]$. Compared with binary treatment variables, if the fruit farmers participate in two value chain activities that affect their production performance, the IPWRA model can be used to set up three treatment levels. $j=0$ indicates that farmers only participate in apple production but not in the value chain activities of the organization; $j=1$ indicates that farmers participate in apple production and the value chain activities of one organization; $j=2$ indicates that farmers participate in apple production and the value chain activities of another organization; and $j=3$ indicates that farmers participate in apple production and the value chain activities of both organizations.

According to Kissoly et al. [90], the IPWRA method involves three steps:

Step 1: The treatment model for the polynomial Logit model is estimated:

$$
p(I=j)=\alpha\left(\mathrm{X}_{\gamma j}\right), \quad \forall j=0,1,2,3
$$

Step 2: The following form of linear regression is used:

$$
Y_{i}(j)=\beta X+\varepsilon, \forall j=0,1,2,3
$$

The linear regression is estimated by the weighted least square method, and the potential outcomes corresponding to all farmers at each treatment level $j$ are predicated. 
Step 3: The average treatment effect is estimated by selecting the average difference of the predicted values for the entire treated sample. The estimated value of ATT in the case of multi-treatment is specified as follows:

$$
\operatorname{ATT}_{j \mid m}=E\left\{Y_{j}-Y_{m} \mid J=j\right\}, \forall m \neq j, j \epsilon J=\{0,1,2,3\}
$$

where $A T T_{j \mid m}$ estimates the expected average effect of participation in value chain activity $j$ relative to value chain activity $\mathrm{m}$. Furthermore, this paper uses the IPWRA model to estimate the treatment effect.

\subsection{Robustness Test}

For the robustness test, the average treatment effect is evaluated with four matching algorithms, and the results show that there is certain robustness [97,98]. However, to eliminate other unobservable factors that affect fruit farmers' decision to participate in the value chain and therefore bias the estimated treatment effect, overlapping tests and balance tests are carried out to analyze the robustness of the results.

\subsubsection{Overlapping Test}

With the explained variable yield per acre as an example, according to the inverse probability weighted estimation results, the overlapping test is carried out, and the study provides the overlapping test diagram of the three value chain activities (Figures 2-4). The results of the overlapping test show that the probability density distribution near 0 and 1 is decentralized, and the distribution of estimated density varies in the overlapping area. Therefore, there is no evidence that the overlap hypothesis is violated. As the propensity scores of the experimental group and the control group have the same value range when the IPWRA model is used, a counterfactual analysis can be performed.

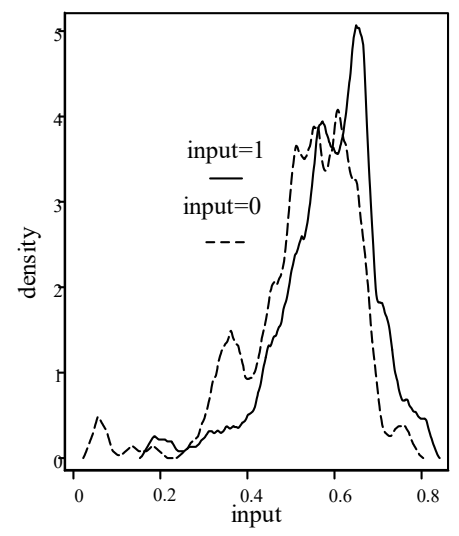

Figure 2. Overlapping test of improved fertilizer input.

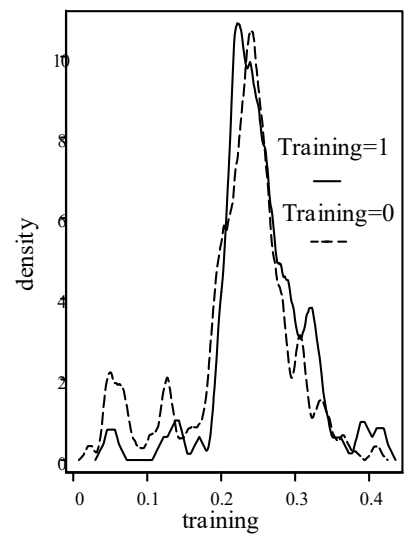

Figure 3. Overlapping test of participating in training. 


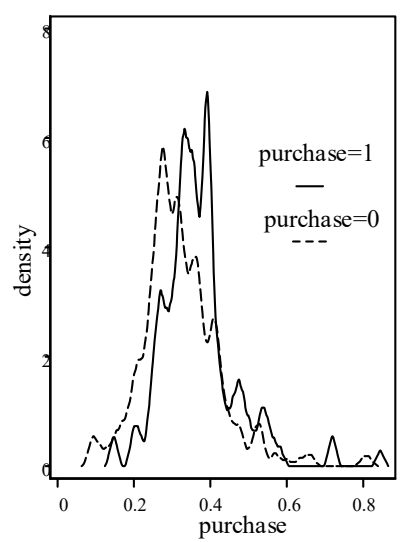

Figure 4. Overlapping test of participating organizations' purchase.

\subsubsection{Balance Test}

The paper carries out a balance test on the explained variable yield per acre and the net income per acre of apple, according to the inverse probability weighted estimation results to ensure the robustness of the estimation results of the IPWRA model. As can be seen from Figures 5 and 6, the control group and the experimental group coincide after matching. Therefore, the model balances the covariates at the intervention level and does not violate the balance hypothesis.

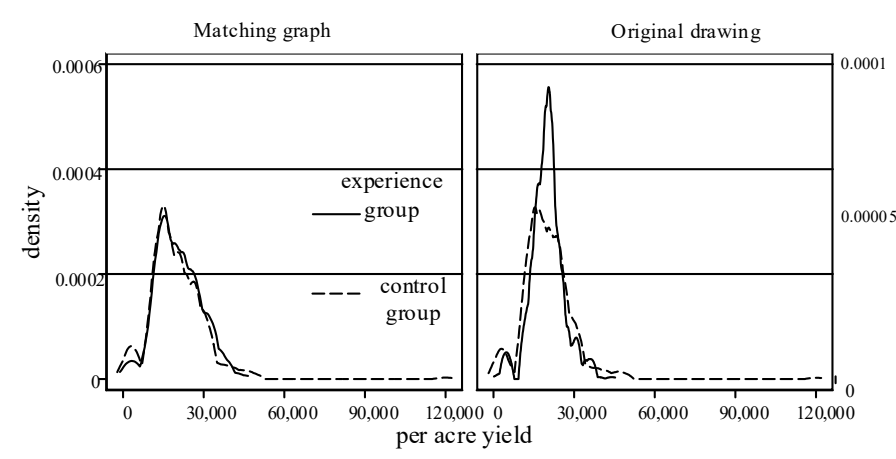

Figure 5. Average yield balance test per acre.

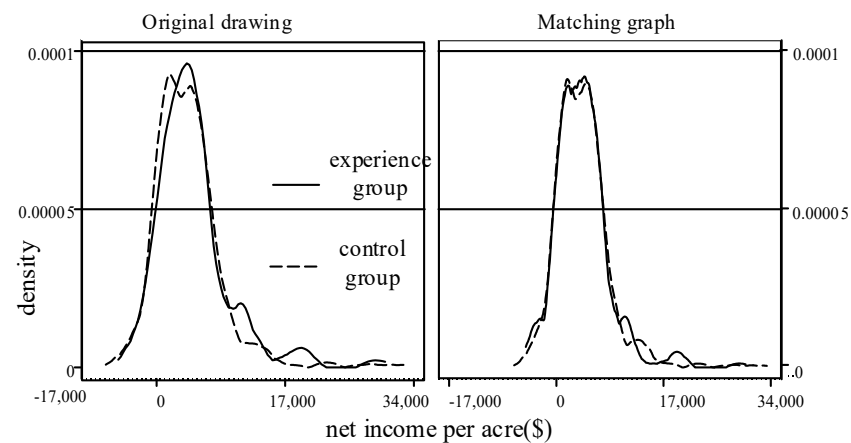

Figure 6. Average net income balance test.

\section{Empirical Test and Result Analysis}

\subsection{Analysis of Influencing Factors of Farmers' Decision to Participate in the Value Chain}

According to the existing PSM research (for example [99-101]), before propensity score matching, the Probit model is first used to screen out the matching variables that affect the selection of three different value chain activities from the listed control variables based on the farmers' behaviour selection theory. The stepwise regression method is then adopted to eliminate the variables that do not significantly affect the farmers' decision-making 
behaviour. The significance level of model variables is weighed to select the appropriate matching variables, as suggested by Jia et al. [102]. As shown in Table 2, the householder's age and the number of days of family labour input have no significant impact on the farmer's decision to participate in the three value chain activities. Distance from the township, participation in cooperatives, and participate in professional training have only positive impacts. The degree of education and household experience in migration for work positively affect improved fertilizer usage provided by the organization. Overall, the fruit farmers' gender has adverse effects on their decision to participate in the value chain. The possible reason is that more respondents are female, and their willingness to participate in value chain-related activities is relatively conservative compared with men. Other significant variables all have a positive impact on fruit farmers' participation in the value chain activities.

Table 2. Estimated results of decision equations of participation in the value chain based on the Probit model.

\begin{tabular}{|c|c|c|c|}
\hline Variable & INPUT & PURCHASE & TRAINING \\
\hline GEN & $-0.0120^{* *}$ & $-0.1210 * *$ & $-0.4330 *$ \\
\hline \multirow{3}{*}{ AGE } & $(0.1240)$ & $(0.1290)$ & $(0.2210)$ \\
\hline & -0.0030 & -0.1170 & -0.0220 \\
\hline & $(0.0070)$ & $(0.0070)$ & $(0.0110)$ \\
\hline \multirow{2}{*}{ EDU } & $0.1340 *$ & 0.1930 * & 0.5640 \\
\hline & $(0.1660)$ & $(0.1750)$ & $(0.3260)$ \\
\hline \multirow[t]{2}{*}{ FAMC } & $0.0640^{* * *}$ & $0.1620 * *$ & 0.0730 ** \\
\hline & $(0.0210)$ & $(0.2140)$ & $(0.0420)$ \\
\hline \multirow[t]{2}{*}{ DIST } & 0.0030 & $0.0090 * *$ & $0.0020^{* *}$ \\
\hline & $(0.0030)$ & $(0.0330)$ & $(0.0060)$ \\
\hline \multirow[t]{2}{*}{ FWJ } & $0.2640^{* * *}$ & $0.1450 * * *$ & $0.1380^{* *}$ \\
\hline & $(0.7340)$ & $(0.6880)$ & $(0.1030)$ \\
\hline \multirow[t]{2}{*}{ AREA } & $0.0050 * *$ & $0.0770 * *$ & $0.0830 * *$ \\
\hline & $(0.0290)$ & $(0.0300)$ & $(0.0530)$ \\
\hline \multirow[t]{2}{*}{ YEARS } & $0.0190^{* *}$ & 0.0080 * & $0.0410^{* *}$ \\
\hline & $(0.0090)$ & $(0.0100)$ & $(0.0170)$ \\
\hline \multirow[t]{2}{*}{ COOP } & 0.0230 & $0.0790^{* * *}$ & $0.7030^{* *}$ \\
\hline & $(0.1500)$ & $(0.1540)$ & $(0.2730)$ \\
\hline \multirow[t]{2}{*}{ SPDE } & 0.1050 ** & 0.6830 * & $0.8610^{* *}$ \\
\hline & $(1.4310)$ & $(1.4720)$ & $(0.2850)$ \\
\hline \multirow[t]{2}{*}{ OUT } & $0.1670^{* *}$ & $0.0810^{* *}$ & - \\
\hline & $(0.1230)$ & $(0.1270)$ & - \\
\hline \multirow[t]{2}{*}{$\mathrm{JR}$} & 0.0010 & 0.0020 & 0.0010 \\
\hline & $(0.0020)$ & $(0.0000)$ & $(0.0030)$ \\
\hline \multirow[t]{2}{*}{ GR } & $0.0070^{* *}$ & 0.0020 ** & 0.0100 ** \\
\hline & $(0.0140)$ & $(0.0020)$ & $(0.0050)$ \\
\hline \multirow[t]{2}{*}{ DZAI } & 0.0720 & $0.4510^{*}$ & $0.1180 * *$ \\
\hline & $(0.2370)$ & $(0.2630)$ & $(0.4640)$ \\
\hline \multirow[t]{2}{*}{ Constant } & $-0.8690^{* * *}$ & $2.6470^{* * *}$ & 8.8730 \\
\hline & $(1.2710)$ & (1.3030) & $(2.6030)$ \\
\hline LR chi2 & 24.72 & 28.40 & 39.51 \\
\hline
\end{tabular}

Note: ${ }^{* * *},{ }^{* *}$, and ${ }^{*}$ indicate that the estimated result is significant at the level of $0.01,0.05$, and 0.1 , respectively; the same below.

Table 2 shows the regression results of selecting matching variables in the decisionmaking process of three different farmers' integration into the value chain. Therefore, the study finally takes eight variables as the common matching variables that affect farmers' decision to participate in the three value chain activities. Farmers' gender, total household 
expenditure, housing value, planting scale, planting years, degree of specialization, days of employment, and whether there is any disaster in three years was carefully explored to conduct an in-depth analysis of the impact of farmers' participation in the value chain on their performance.

\subsection{Empirical Result Analysis of Propensity Score Matching}

This paper uses the PSM model and selected matching variables to analyze the average treatment effect of the impact of various value chain activities (fruit farmers' use of improved fertilizer provided by the organization, participation in the training and purchase by the organization) on agricultural production performance, under which the nearest neighbour matching, caliper matching, kernel matching, and radius matching, and comparative analysis are carried out.

Table 3 shows the average impact of the three value chain activities on yield per acre and net income per acre. Among them, improved fertilizer and the participation in the purchase by the organization have a significant positive impact on the yield per acre and net income per acre of apples. Therefore, Hypotheses 1 and 3 can be verified to some extent. However, participation in training has no significant impact on farmers' performance, so Hypothesis 2 is not verified. The results calculated by nearest-neighbour matching, caliper matching, kernel matching, and radius matching all show that the average yield per acre of fruit farmers using improved fertilizer is increased by $4285.74 \mathrm{~kg}$, and the average net income per acre is increased by $\$ 2146.64$ as compared with those not using the improved fertilizer. Moreover, the average yield per acre of fruit farmers participating in the purchase by the industrial organizations is increased by $3711.49 \mathrm{~kg}$, and the average net income per acre increased by $\$ 1809.76$.

Table 3. Average treatment effect of yield per acre and net income per acre based on the PSM model.

\begin{tabular}{|c|c|c|c|c|c|}
\hline Variable & Nearest Neighbor Matching & Caliper Matching & Kernel Matching & Radius Matching & Mean \\
\hline \multicolumn{6}{|l|}{ Improved fertilizer } \\
\hline Yield per acre (kg) & $\$ 597.93 * * *$ & $\$ 637.77^{* * *}$ & $\$ 606.06^{* * *}$ & $\$ 609.69 * * *$ & $\$ 612.86$ \\
\hline Net income per acre $(\$)$ & $\$ 2160.47^{* * *}$ & $\$ 2103.07^{* * *}$ & $\$ 2114.88^{* * *}$ & $\$ 2208.14^{* * *}$ & $\$ 2146.64$ \\
\hline \multicolumn{6}{|l|}{ Purchase by the organization } \\
\hline Yield per acre $(\mathrm{kg})$ & $\$ 484.85^{* * *}$ & $\$ 489.59 * * *$ & $\$ 575.89 * * *$ & $\$ 572.64^{* * *}$ & $\$ 530.74$ \\
\hline Net income per acre $(\$)$ & $\$ 1831.42 * * *$ & $\$ 1831.00 * * *$ & $\$ 1780.33 * * *$ & $\$ 1796.30 * * *$ & $\$ 1809.76$ \\
\hline \multicolumn{6}{|l|}{ Participation in training } \\
\hline Yield per acre (kg) & $\$ 35.09$ & $\$ 27.35$ & $\$ 7.02$ & $\$ 31.62$ & $\$ 25.27$ \\
\hline Net income per acre $(\$)$ & $\$ 533.59$ & $\$ 459.89$ & $\$ 323.80$ & $\$ 478.17$ & $\$ 448.86$ \\
\hline
\end{tabular}

Note: ${ }^{* * *}$ means $p$ is less than 0.01 .

4.3. Comparative Analysis on the Impact of Fruit Farmers' Participation in One or More Value Chain Activities on Their Agricultural Production Performance

As the participation in training does not have a significant impact on fruit farmers' production performance, only two value chain activities, namely, improved fertilizer and purchase by the organization, are selected for analyzing the impact of the extent of fruit farmers' participation in the value chain on their production performance. According to the statistical analysis of basic data, 128 fruit farmers only use the improved fertilizer, 92 fruit farmers only participate the organization's purchasing, and 86 fruit farmers participate in both value chain activities. The sample number is subject to multi-value intervention effect analysis. The analysis results are shown in Table 4. 
Table 4. Average treatment effect of yield per acre and net income per acre based on the IPWRA model.

\begin{tabular}{ccccc}
\hline Variable & Average Treatment Effect & SD & Percentage & SD \\
\hline Yield per acre & & & & \\
$(1$ vs. $)$ & $3254.89^{* * *}$ & 998.87 & $18.59 \% * * *$ & 0.06 \\
$(2$ vs. $)$ & $3560.34^{* * *}$ & 1142.06 & $20.34 \% * * *$ & 0.07 \\
$(3$ vs. $)$ & $5681.30^{* * *}$ & 1395.74 & $32.45 \% * * *$ & 0.09 \\
$(2$ vs. $)$ & 290.16 & 1215.82 & $1.40 \%$ & 0.05 \\
$(3$ vs. $)$ & $2375.61^{*}$ & 1399.08 & $11.43 \% *$ & 0.06 \\
( 3 vs. $)$ & $2085.45^{*}$ & 1476.48 & $9.90 \%$ & 0.07 \\
Net income per acre & & & & \\
$(1$ vs. $)$ & $\$ 2517.15^{* * *}$ & 520.44 & $92.98 \% * * *$ & 0.27 \\
$(2$ vs. $)$ & $\$ 2379.42^{* * *}$ & 483.23 & $87.89 \% * * *$ & 0.26 \\
$(3$ vs. $)$ & $\$ 4002.91^{* * *}$ & 861.78 & $147.87 \% * * *$ & 0.41 \\
$(2$ vs. $)$ & $-\$ 137.70$ & 573.31 & $-2.60 \%$ & 0.11 \\
$(3$ vs. $)$ & $\$ 1470.08^{*}$ & 895.43 & $28.19 \% *$ & 0.18 \\
$(3$ vs. $)$ & $\$ 1607.79^{*}$ & 877.66 & $31.67 \% *$ & 0.18 \\
\hline
\end{tabular}

Note: ${ }^{*}$ means $p$ is less than $0.1 ;{ }^{* * *}$ means $p$ is less than 0.01 . In Table 4,1 vs. 0 compares the performance of fruit farmers using improved fertilizer and those without participating in any value chain activities; $2 \mathrm{vs} .0$ compares the performance of fruit farmers participating in the purchase by the organization and those without participating in any value chain activities; 3 vs. 0 compares the performance of fruit farmers using improved fertilizer and participating in the purchase by the organization and those without participating in any value chain activities; 2 vs. 1 compares the performance of fruit farmers using improved fertilizer and those participating in the purchase by the organization; 3 vs. 1 compares the performance of fruit farmers participating in both value chain activities and those only using improved fertilizer; 3 vs. 2 compares the performance of fruit farmers participating in both value chain activities and those only participating in the purchase by the organization.)

The empirical results of IPWRA show that no matter the yield per acre or the net income per acre, 1 vs. 0,2 vs. 0 , and 3 vs. 0 have passed the significance test. Therefore, Hypotheses 1 and 3 are further verified, which indicates that compared with non-participating fruit farmers, the average yield per acre of fruit farmers participating in one or more value chain activities can be increased by $3254.89 \mathrm{~kg}$, $3560.34 \mathrm{~kg}$, and $5681.30 \mathrm{~kg}$, respectively, with an increased ratio of $18.59 \%, 20.34 \%$, and $32.45 \%$, respectively. Similarly, through the participation in one or more of the above value chain activities, the average net income per acre of fruit farmers can be increased by $\$ 2517.15, \$ 2379.42$, and $\$ 4002.91$, respectively, compared with that of non-participating fruit farmers, with an increased ratio of $92.98 \%$, $87.89 \%$, and $147.87 \%$, respectively (Table 4 ).

According to the comparison between fruit farmers participating in both value chain activities and those only participating in one value chain activity, the yield per acre and the net income per acre show a certain difference. As for yield per acre, fruit farmers participating in both value chain activities produce a significant positive impact on yield per acre compared with those only using improved fertilizer. Specifically, the yield per acre is increased by $2375.61 \mathrm{~kg}$ on average, with an increased ratio of $11.43 \%$. However, when it comes to fruit farmers participating in both value chain activities and those only participating in the purchase by the organization, the influence on yield per acre is not significant. As for net income per acre, compared with those only using improved fertilizers or participating in the purchase by the organization, fruit farmers participating in both value chain activities have higher improved fertilizer, increased by $\$ 1470.08$ and $\$ 1607.79$, respectively, with an increased ratio of $28.19 \%$ and $31.67 \%$, respectively (Table 4 ).

\section{Conclusions}

Based on the survey data of apple growers in Shandong, this paper analyzes farmers' participation in the agricultural value chain on their production performance with the PSM model and the IPWRA model. The main conclusions are as follows. (1) Fruit farmers' gender, total household expenditure, housing value, planting scale, planting years, degree of specialization, days of family labour input, days of employment, and whether there is a freeze-up disaster in three years have significant effects on their participation in the three value chain activities. Although the fruit farmers' gender has adverse effects on their 
decision to participate in the value chain activities, other significant variables positively impact fruit farmers' participation. (2) Compared with those who do not participate in any value chain activity, fruit farmers participating in value chain activities tend to have a higher yield per acre and net income per acre. According to empirical analysis, the yield per acre of fruit farmers participating in both value chain activities is increased compared with those only using improved fertilizer. However, it has no significant difference for those only participating in the purchase by the organization. Moreover, the net income per acre of fruit farmers participating in both value chain activities is greatly increased compared with those only using improved fertilizer or only participating in the purchase by the organization. Based on the assessments and observation, we crafted the following policy recommendations:

First, the government should support and encourage farmers to participate in the value chain of industrial organizations through fiscal and monetary policies such as financial support and credit incentives. Participation in cooperatives will, to some extent, affect farmers' decision-making behaviour regarding participating in the industrial chain. Thus, the government can provide special subsidized funds to new agricultural organizations such as farmers' cooperatives directly to all producers through project funds (such as special fertilizer subsidies). A vast number of farmers can benefit from the improvement of agricultural inputs. When the well-structured link is established between small farmers and modern agriculture, they are empowered to expand their survival and development space regardless of their products or factors.

Second, the government should strengthen the training of farmers' production technology and capability. Although fruit farmers' participation in guidance training does not significantly improve their production performance, strengthened agricultural technology training and management is conducive to comprehensively improving their agricultural production level, which is conducive to improving the overall performance of agricultural production as farmers participate in value chain activities. Therefore, from the strategic perspective of promoting the high-quality development of agriculture, industrial organizations and relevant government departments should continue to organize series of activities that help improve the agricultural value chain, such as "science and technology going countryside", and encourage the vast number of small and medium-sized farmers to actively participate in the agricultural value chain.

Finally, it is recommended that relevant government departments actively carry out activities to link industrial organizations and farmers' participation in the industrial chain so that farmers can actively integrate into the value chain. As there are certain limitations on farmers' understanding of the role of participation in the value chain, they may doubt the use of factors of production provided by industrial organizations and the participation in the purchase by the organizations at the beginning. Therefore, relevant government departments must continuously organize promotional activities of typical farmers' participation in the value chain, increasing farmers' courage and confidence in participating in the value chain and realizing an overall performance improvement.

Author Contributions: Conceptualization, F.Z., and A.S.; methodology, F.Z. and X.W.; software, H.W. and X.W.; validation, F.Z., H.W. and A.S.; formal analysis, F.Z. and A.S.; investigation, A.S.; resources, H.W. and X.W.; data curation, H.W. and X.W.; writing-original draft preparation, F.Z.; writing-review and editing, A.S.; visualization, F.Z.; supervision, H.W.; project administration, A.S.; funding acquisition, F.Z., X.W. and H.W. All authors have read and agreed to the published version of the manuscript.

Funding: This research was funded by "Shandong Provincial Social Science Planning Research Project" grant number "ZR2018MG013", and "Shandong Provincial Social Science Planning Research Project" grant number "20CSDJ44".

Institutional Review Board Statement: Ethical review and approval were waived for this study as the study does not collect any personal data of the respondents and respondents was clearly informed that they can opt out any time if they want from giving the response. 
Informed Consent Statement: Informed consent was obtained from all subjects involved in the study.

Data Availability Statement: The data are available upon request from the corresponding author.

Conflicts of Interest: The authors declare there is no conflict of interest associated with the study.

\section{References}

1. Poole, N. Smallholder Agriculture and Market Participation; Practical Action Publishing/Food and Agriculture Organization of the United Nations (FAO): Rugby, UK, 2017; ISBN 92-5-109939-1.

2. Webber, C.M.; Labaste, P. Building Competitiveness in Africa's Agriculture: A Guide to Value Chain Concepts and Applications; The World Bank: Bretton Woods, NH, USA, 2009; ISBN 0-8213-7952-6.

3. Acevedo, M.; Pixley, K.; Zinyengere, N.; Meng, S.; Tufan, H.; Cichy, K.; Bizikova, L.; Isaacs, K.; Ghezzi-Kopel, K.; Porciello, J. A Scoping Review of Adoption of Climate-Resilient Crops by Small-Scale Producers in Low- and Middle-Income Countries. Nat. Plants 2020, 6, 1231-1241. [CrossRef]

4. Yates, J.; Deeney, M.; Rolker, H.B.; White, H.; Kalamatianou, S.; Kadiyala, S. A Systematic Scoping Review of Environmental, Food Security and Health Impacts of Food System Plastics. Nat. Food 2021, 2, 80-87. [CrossRef]

5. Bezemer, D.; Headey, D. Agriculture, Development, and Urban Bias. World Dev. 2008, 36, 1342-1364. [CrossRef]

6. Pinstrup-Andersen, P.; Shimokawa, S. Rural Infrastructure and Agricultural Development; World Bank: Bretton Woods, NH, USA, 2006.

7. Liu, L. Assessment of Water Resource Security in Karst Area of Guizhou Province, China. Sci. Rep. 2021, 11, 7641. [CrossRef] [PubMed]

8. Bachev, H. Management of Environmental Challenges and Sustainability of Bulgarian Agriculture. In Environmental Change and Human Security: Recognizing and Acting on Hazard Impacts; Liotta, P.H., Mouat, D.A., Kepner, W.G., Lancaster, J.M., Eds.; Springer: Dordrecht, The Netherlands, 2008; pp. 117-142.

9. Lazrak, E.G.; Mari, J.-F.; Benoît, M. Landscape Regularity Modelling for Environmental Challenges in Agriculture. Landsc. Ecol. 2010, 25, 169-183. [CrossRef]

10. Xu, Z.; Chen, X.; Liu, J.; Zhang, Y.; Chau, S.; Bhattarai, N.; Wang, Y.; Li, Y.; Connor, T.; Li, Y. Impacts of Irrigated Agriculture on Food-Energy-Water-CO 2 Nexus across Metacoupled Systems. Nat. Commun. 2020, 11, 5837. [CrossRef]

11. Pereira, L.S. Water, Agriculture and Food: Challenges and Issues. Water Resour. Manag. 2017, 31, 2985-2999. [CrossRef]

12. Rapsomanikis, G. The Economic Lives of Smallholder Farmers: An Analysis Based on Household Data from Nine Countries; Food Agric. Organ. U. N.: Rome, Italy, 2015; pp. 1-3.

13. Barrett, C.B. Smallholder Market Participation: Concepts and Evidence from Eastern and Southern Africa. Food Policy 2008, 33, 299-317. [CrossRef]

14. Mitiku, A. Impact of Smallholder Farmers Agricultural Commercialization on Rural Households' Poverty. Int. J. Appl. Econ. Finance 2014, 8, 51-61. [CrossRef]

15. Muller, A.; Schader, C.; El-Hage Scialabba, N.; Brüggemann, J.; Isensee, A.; Erb, K.-H.; Smith, P.; Klocke, P.; Leiber, F.; Stolze, M.; et al. Strategies for Feeding the World More Sustainably with Organic Agriculture. Nat. Commun. 2017, 8, 1290. [CrossRef] [PubMed]

16. Liverpool-Tasie, L.S.O.; Wineman, A.; Young, S.; Tambo, J.; Vargas, C.; Reardon, T.; Adjognon, G.S.; Porciello, J.; Gathoni, N.; Bizikova, L.; et al. A Scoping Review of Market Links between Value Chain Actors and Small-Scale Producers in Developing Regions. Nat. Sustain. 2020, 3, 799-808. [CrossRef]

17. Alene, A.D.; Manyong, V.M.; Omanya, G.; Mignouna, H.D.; Bokanga, M.; Odhiambo, G. Smallholder Market Participation under Transactions Costs: Maize Supply and Fertilizer Demand in Kenya. Food Policy 2008, 33, 318-328. [CrossRef]

18. Lapar, M.L.; Holloway, G.; Ehui, S. Policy Options Promoting Market Participation among Smallholder Livestock Producers: A Case Study from the Phillipines. Food Policy 2003, 28, 187-211. [CrossRef]

19. Stathers, T.; Holcroft, D.; Kitinoja, L.; Mvumi, B.M.; English, A.; Omotilewa, O.; Kocher, M.; Ault, J.; Torero, M. A Scoping Review of Interventions for Crop Postharvest Loss Reduction in Sub-Saharan Africa and South Asia. Nat. Sustain. $2020,3,821-835$. [CrossRef]

20. Gao, Y.; Liu, Z.; Li, R.; Shi, Z. Long-Term Impact of China's Returning Farmland to Forest Program on Rural Economic Development. Sustainability 2020, 12, 1492. [CrossRef]

21. Timmer, C.P. Chapter 29 Agriculture and economic development. In Handbook of Agricultural Economics; Agriculture and Its External Linkages; Elsevier: Amsterdam, The Netherlands, 2002; Volume 2, pp. 1487-1546.

22. Hernández, R.; Reardon, T.; Berdegué, J. Supermarkets, Wholesalers, and Tomato Growers in Guatemala. Agric. Econ. 2007, 36, 281-290. [CrossRef]

23. Holloway, G.; Lapar, M.L.A. How Big Is Your Neighbourhood? Spatial Implications of Market Participation Among Filipino Smallholders. J. Agric. Econ. 2007, 58, 37-60. [CrossRef]

24. Clapp, J. CRFA-ABCD and beyond: From Grain Merchants to Agricultural Value Chain Managers. Can. Food Stud. Rev. Can. Études Sur Aliment. 2015, 2, 126-135. [CrossRef]

25. Kilelu, C.; Klerkx, L.; Omore, A.; Baltenweck, I.; Leeuwis, C.; Githinji, J. Value Chain Upgrading and the Inclusion of Smallholders in Markets: Reflections on Contributions of Multi-Stakeholder Processes in Dairy Development in Tanzania. Eur. J. Dev. Res. 2017, 29, 1102-1121. [CrossRef] 
26. Fan, S. Economics in Food Systems Transformation. Nat. Food 2021, 2, 218-219. [CrossRef]

27. Kocho, T.; Abebe, G.; Tegegne, A.; Gebremedhin, B. Marketing Value-Chain of Smallholder Sheep and Goats in Crop-Livestock Mixed Farming System of Alaba, Southern Ethiopia. Small Rumin. Res. 2011, 96, 101-105. [CrossRef]

28. Mcmichael, P. Value-Chain Agriculture and Debt Relations: Contradictory Outcomes. Third World Q. 2013, 34, 671-690. [CrossRef]

29. De Brauw, A.; Kramer, B.; Murphy, M. Migration, Labor and Women's Empowerment: Evidence from an Agricultural Value Chain in Bangladesh. World Dev. 2021, 142, 105445. [CrossRef] [PubMed]

30. Liying, W.; Shuyu, D.; Houping, L.I.U. Organic Connection between Small Farmers and Modern Agriculture Development Based on Farmers' Cooperatives in China. Asian Agric. Res. 2020, 12, 1-9. [CrossRef]

31. Yang, S.; Chen, J. Organic Connection between Small Farmers and Modern Agriculture in China: Obstacles and Solutions. High Educ. Soc. Sci. 2019, 16, 1-4. [CrossRef]

32. Soundarrajan, P.; Vivek, N. A Study on the Agricultural Value Chain Financing in India. Agric. Econ. 2015, 61, 31-38. [CrossRef]

33. Trebbin, A. Linking Small Farmers to Modern Retail through Producer Organizations-Experiences with Producer Companies in India. Food Policy 2014, 45, 35-44. [CrossRef]

34. Trienekens, J.H. Agricultural Value Chains in Developing Countries; a Framework for Analysis. Int. Food Agribus. Manag. Rev. 2011, 14, 51-83.

35. Von Loeper, W.J.; Drimie, S.; Blignaut, J. The Struggles of Smallholder Farmers: A Cause of Modern Agricultural Value Chains in South Africa. Agric. Value Chain 2018, 161, 75710.

36. Halewood, N.J.; Surya, P. Mobilizing the Agricultural Value Chain. Inf. Commun. Dev. 2012 Maximizing Mob. 2012, 31-42. [CrossRef]

37. JingZhong, Y.; ShuLong, D.; MingHao, Z. How can small farmers become organically involved in the development of modern agriculture? China Rural Econ. 2018, 11, 20183391248.

38. Huang, J.; Wang, X.; Qiu, H. Small-Scale Farmers in China in the Face of Modernisation and Globalisation; IIEDHIVOS: London, UK; Hague, The Netherlands, 2012.

39. Purcell, S.W.; Crona, B.I.; Lalavanua, W.; Eriksson, H. Distribution of Economic Returns in Small-Scale Fisheries for International Markets: A Value-Chain Analysis. Mar. Policy 2017, 86, 9-16. [CrossRef]

40. Zhang, X.; Qing, P.; Yu, X. Short Supply Chain Participation and Market Performance for Vegetable Farmers in China. Aust. J. Agric. Resour. Econ. 2019, 63, 282-306. [CrossRef]

41. Van Bergen, M.; Steeman, M.; Reindorp, M.; Gelsomino, L. Supply Chain Finance Schemes in the Procurement of Agricultural Products. J. Purch. Supply Manag. 2019, 25, 172-184. [CrossRef]

42. Rørstad, P.K.; Vatn, A.; Kvakkestad, V. Why Do Transaction Costs of Agricultural Policies Vary? Agric. Econ. 2007, 36, 1-11. [CrossRef]

43. Pingali, P.; Khwaja, Y.; Meijer, M. The Role of the Public and Private Sectors in Commercializing Small Farms and Reducing Transaction Costs. Glob. Supply Chains Stand. Poor Camb. MA CAB Int. 2007, 267-280. [CrossRef]

44. Ammenberg, J.; Wik, G.; Hjelm, O. Auditing External Environmental Auditors-Investigating How ISO 14001 Is Interpreted and Applied in Reality. Eco-Manag. Audit. 2001, 8, 183-192. [CrossRef]

45. Andersen, T.B.; Jensen, P.S.; Skovsgaard, C.V. The Heavy Plow and the Agricultural Revolution in Medieval Europe. J. Dev. Econ. 2016, 118, 133-149. [CrossRef]

46. Ola, K.O. Micro-determinants of Women's Participation in Agricultural Value Chain: Evidence from Rural Households in Nigeria. In The Palgrave Handbook of Agricultural and Rural Development in Africa; Osabuohien, E.S., Ed.; Springer International Publishing: Cham, Switzerland, 2020; pp. 553-570. ISBN 978-3-030-41513-6.

47. Elbehri, A.; Lee, M. Role of Women Producer Organizations in Agricultural Value Chains; FAO: Rome, Italy, 2011.

48. Govoeyi, B.; Ahounou, S.G.; Agbokounou, A.M.; Salifou, C.F.A.; Dotche, I.O.; Kiki, P.S.; Youssao Abdou Karim, I.; AntoineMoussiaux, N. Participatory Innovation Analysis along Livestock Value Chains: Case of Swine Value Chain in Benin. Agric. Syst. 2019, 174, 11-22. [CrossRef]

49. Ndyetabula, D.W.; Sørensen, O.J.; Temu, A.A. Agribusiness Development and the Role of Value Chain Business Associations: The Case of Dried Fruits and Vegetables in Tanzania. Afr. J. Econ. Manag. Stud. 2016, 7, 510-534. [CrossRef]

50. Manda, J.; Khonje, M.G.; Alene, A.D.; Tufa, A.H.; Abdoulaye, T.; Mutenje, M.; Setimela, P.; Manyong, V. Does Cooperative Membership Increase and Accelerate Agricultural Technology Adoption? Empirical Evidence from Zambia. Technol. Forecast. Soc. Change 2020, 158, 120160. [CrossRef]

51. Preckel, P.V.; Gray, A.; Boehlje, M.; Kim, S. Risk and Value Chains: Participant Sharing of Risk and Rewards. J. Chain Netw. Sci. 2004, 4, 25-32. [CrossRef]

52. Xu, G.; Sarkar, A.; Qian, L. Does Organizational Participation Affect Farmers' Behavior in Adopting the Joint Mechanism of Pest and Disease Control? A Study of Meixian County, Shaanxi Province. Pest Manag. Sci. 2020. [CrossRef] [PubMed]

53. Bijman, J.; Muradian, R.; Cechin, A. Agricultural cooperatives and value chain coordination: Jos Bijman, Roldan Muradian and Andrei Cechin. In Value Chains, Social Inclusion and Economic Development; Routledge: Abingdon, UK, 2010; pp. 82-101. ISBN 978-0-203-81680-6.

54. Higgins, A.J.; Miller, C.J.; Archer, A.A.; Ton, T.; Fletcher, C.S.; McAllister, R.R.J. Challenges of Operations Research Practice in Agricultural Value Chains. J. Oper. Res. Soc. 2010, 61, 964-973. [CrossRef] 
55. Ho, K.L.P.; Nguyen, C.N.; Adhikari, R.; Miles, M.P.; Bonney, L. Exploring Market Orientation, Innovation, and Financial Performance in Agricultural Value Chains in Emerging Economies. J. Innov. Knowl. 2018, 3, 154-163. [CrossRef]

56. Taylor, D.H. Value Chain Analysis: An Approach to Supply Chain Improvement in Agri-food Chains. Int. J. Phys. Distrib. Logist. Manag. 2005, 35, 744-761. [CrossRef]

57. Swinnen, J. Value Chains, Agricultural Markets and Food Security; State Agric. Commod. Mark. Food Agric. Organ. U. N. FAO: Rome, Italy, 2015.

58. Neven, D. Developing Sustainable Food Value Chains, Guiding Principles; FAO: Rome, Italy, 2014.

59. Gómez, M.I.; Meemken, E.; Verteramo Chiu, L.J. Agricultural Value Chains and Social and Environmental Impacts: Trends, Challenges, and Policy Options: Background Paper for The State of Agricultural Commodity Markets (SOCO) 2020; FAO: Rome, Italy, 2020; ISBN 978-92-5-133201-6.

60. Humphrey, J. Policy Implications of Trends in Agribusiness Value Chains. Eur. J. Dev. Res. 2006, 18, 572-592. [CrossRef]

61. IFAD. Rural Development Report 2016: Fostering Inclusive Rural Transformation; International Fund for Agricultural Development: Rome, Italy, 2016.

62. Gómez, M.I.; Barrett, C.B.; Buck, L.E.; De Groote, H.; Ferris, S.; Gao, H.O.; McCullough, E.; Miller, D.D.; Outhred, H.; Pell, A.N.; et al. Agriculture. Research Principles for Developing Country Food Value Chains. Science 2011, 332, 1154-1155. [CrossRef]

63. Bolzani, D.; de Villard, S.; de Pryck, J.D. Agricultural Value Chain Development: Threat Or Opportunity for Women's Employment? ILO: Geneva, Switzerland, 2010.

64. Kumar, A.; Singh, H.; Kumar, S.; Mittal, S. Value Chains of Agricultural Commodities and Their Role in Food Security and Poverty Alleviation-A Synthesis. Agric. Econ. Res. Rev. 2011, 24, 169-181.

65. Hassan, S.Z.; Jajja, M.S.S.; Asif, M.; Foster, G. Bringing More Value to Small Farmers: A Study of Potato Farmers in Pakistan. Manag. Decis. 2020. [CrossRef]

66. Mutonyi, S. The Effect of Collective Action on Smallholder Income and Asset Holdings in Kenya. World Dev. Perspect. 2019, 14, 100099. [CrossRef]

67. Parikh, T.S.; Patel, N.; Schwartzman, Y. A Survey of Information Systems Reaching Small Producers in Global Agricultural Value Chains. In Proceedings of the 2007 International Conference on Information and Communication Technologies and Development, Bangalore, India, 15-16 December 2007; pp. 1-11.

68. Louw, A.; Vermeulen, H.; Kirsten, J.; Madevu, H. Securing Small Farmer Participation in Supermarket Supply Chains in South Africa. Dev. South. Afr. 2007, 24, 539-551. [CrossRef]

69. Rao, E.J.O.; Brümmer, B.; Qaim, M. Farmer Participation in Supermarket Channels, Production Technology, and Efficiency: The Case of Vegetables in Kenya. Am. J. Agric. Econ. 2012, 94, 891-912. [CrossRef]

70. Thiele, G.; Devaux, A.; Reinoso, I.; Pico, H.; Montesdeoca, F.; Pumisacho, M.; Andrade-Piedra, J.; Velasco, C.; Flores, P.; Esprella, R.; et al. Multi-Stakeholder Platforms for Linking Small Farmers to Value Chains: Evidence from the Andes. Int. J. Agric. Sustain. 2011, 9, 423-433. [CrossRef]

71. Kilelu, C.W.; Klerkx, L.; Leeuwis, C. Supporting Smallholder Commercialisation by Enhancing Integrated Coordination in Agrifood Value Chains: Experiences with Dairy Hubs in Kenya. Exp. Agric. 2017, 53, 269-287. [CrossRef]

72. Negi, D.S.; Birthal, P.S.; Roy, D.; Khan, M.T. Farmers' Choice of Market Channels and Producer Prices in India: Role of Transportation and Communication Networks. Food Policy 2018, 81, 106-121. [CrossRef]

73. Holdings, B.S. Making Fruit Happy: Blue Skies Sustainability Report 2008; Blue Ski. Hold. Ltd.: Northants, UK, 2009.

74. Hanf, J.H. Processor Driven Integration of Small-Scale Farmers into Value Chains in Eastern Europe and Central Asia; Food and Agriculture Organization of United Nations: Porec, Croatia, 2014.

75. Miller, C.; Jones, L. Agricultural Value Chain Finance: Tools and Lessons; Practical Action: Warwickshire, UK, 2010; ISBN 1-78044-051-0.

76. Swamy, V.; Dharani, M. Analyzing the Agricultural Value Chain Financing: Approaches and Tools in India. Agric. Financ. Rev. 2016, 76, 211-232. [CrossRef]

77. Markelova, H.; Meinzen-Dick, R.; Hellin, J.; Dohrn, S. Collective Action for Smallholder Market Access. Food Policy 2009, 34, 1-7. [CrossRef]

78. Hanf, J.H.; Gagalyuk, T. Integration of Small Farmers into Value Chains: Evidence from Eastern Europe and Central Asia. Agric. Value Chain 2018. [CrossRef]

79. Minten, B.; Singh, K.M.; Sutradhar, R. Branding and Agricultural Value Chains in Developing Countries: Insights from Bihar (India). Food Policy 2013, 38, 23-34. [CrossRef]

80. Alam, G.; Verma, D. Connecting Small Farmers With Dynamic Markets: A Successful Supply Chain in Uttarakhand, India. In Linking Smallholder Producers to Modern Agri-Food Chains: Case Studies from South Asia, Southeast Asia and China; Allied Publishers Pvt Ltd.: New Delhi, India, 2013; pp. 76-96.

81. Aliguma, L.; Magala, D.; Lwasa, S. Uganda: Connecting Small-Scale Producers to Markets: The Case of the Nyabyumba United Farmers Group in Kabale District; Regoverning Markets Innovative Practice Series; International Institute for Environment and Development: London, UK, 2007.

82. Abadie, A.; Imbens, G.W. Matching on the Estimated Propensity Score. Econometrica 2016, 84, 781-807. [CrossRef]

83. Liu, X.; Lynch, L. Do Agricultural Land Preservation Programs Reduce Farmland Loss? Evidence from a Propensity Score Matching Estimator. Land Econ. 2011, 87, 183-201. [CrossRef] 
84. Dehejia, R.H.; Wahba, S. Propensity Score-Matching Methods for Nonexperimental Causal Studies. Rev. Econ. Stat. 2002, 84, 151-161. [CrossRef]

85. Wilde, E.T.; Hollister, R. How Close Is Close Enough? Evaluating Propensity Score Matching Using Data from a Class Size Reduction Experiment. J. Policy Anal. Manage. 2007, 26, 455-477. [CrossRef]

86. Wong, D.F.K. Cognitive Behavioral Treatment Groups for People with Chronic Depression in Hong Kong: A Randomized Wait-List Control Design. Depress. Anxiety 2008, 25, 142-148. [CrossRef]

87. Abass, A.B.; Ndunguru, G.; Mamiro, P.; Alenkhe, B.; Mlingi, N.; Bekunda, M. Post-Harvest Food Losses in a Maize-Based Farming System of Semi-Arid Savannah Area of Tanzania. J. Stored Prod. Res. 2014, 57, 49-57. [CrossRef]

88. Caliendo, M.; Kopeinig, S. Some Practical Guidance for the Implementation of Propensity Score Matching. J. Econ. Surv. 2008, 22, 31-72. [CrossRef]

89. Lechner, M. Program Heterogeneity and Propensity Score Matching: An Application to the Evaluation of Active Labor Market Policies. Rev. Econ. Stat. 2002, 84, 205-220. [CrossRef]

90. Kissoly, L.; Faße, A.; Grote, U. The Integration of Smallholders in Agricultural Value Chain Activities and Food Security: Evidence from Rural Tanzania. Food Secur. 2017, 9, 1219-1235. [CrossRef]

91. Curtis, L.H.; Hammill, B.G.; Eisenstein, E.L.; Kramer, J.M.; Anstrom, K.J. Using Inverse Probability-Weighted Estimators in Comparative Effectiveness Analyses with Observational Databases. Med. Care 2007, 45, S103-S107. [CrossRef] [PubMed]

92. Rotnitzky, A.; Li, L.; Li, X. A Note on Overadjustment in Inverse Probability Weighted Estimation. Biometrika 2010, 97, 997-1001. [CrossRef]

93. Seaman, S.R.; White, I.R. Review of Inverse Probability Weighting for Dealing with Missing Data. Stat. Methods Med. Res. 2013, 22, 278-295. [CrossRef]

94. Raad, H.; Cornelius, V.; Chan, S.; Williamson, E.; Cro, S. An Evaluation of Inverse Probability Weighting Using the Propensity Score for Baseline Covariate Adjustment in Smaller Population Randomised Controlled Trials with a Continuous Outcome. BMC Med. Res. Methodol. 2020, 20, 70. [CrossRef]

95. Tambo, J.A.; Mockshell, J. Differential Impacts of Conservation Agriculture Technology Options on Household Income in Sub-Saharan Africa. Ecol. Econ. 2018, 151, 95-105. [CrossRef]

96. Sseguya, H.; Robinson, D.S.; Mwango, H.R.; Flock, J.A.; Manda, J.; Abed, R.; Mruma, S.O. The Impact of Demonstration Plots on Improved Agricultural Input Purchase in Tanzania: Implications for Policy and Practice. PLoS ONE 2021, 16, e0243896. [CrossRef] [PubMed]

97. Asfaw, S.; Shiferaw, B.; Simtowe, F.; Hagos, M. Agricultural Technology Adoption, Seed Access Constraints and Commercialization in Ethiopia. J. Dev. Agric. Econ. 2011, 3, 436-477.

98. Słoczyński, T.; Wooldridge, J.M. A General Double Robustness Result for Estimating Average Treatment Effects. Econom. Theory 2018, 34, 112-133. [CrossRef]

99. Shadish, W.R.; Steiner, P.M. A Primer on Propensity Score Analysis. Newborn Infant Nurs. Rev. 2010, 10, 19-26. [CrossRef]

100. Rubin, D.B.; Thomas, N. Combining Propensity Score Matching with Additional Adjustments for Prognostic Covariates. J. Am. Stat. Assoc. 2000, 95, 573-585. [CrossRef]

101. Thoemmes, F.J.; Kim, E.S. A Systematic Review of Propensity Score Methods in the Social Sciences. Multivar. Behav. Res. 2011, 46, 90-118. [CrossRef] [PubMed]

102. Jia, R.; Fang, S.; Tu, W.; Sun, Z. Driven Factors Analysis of China's Irrigation Water Use Efficiency by Stepwise Regression and Principal Component Analysis. Discrete Dyn. Nat. Soc. 2016, 2016, e8957530. [CrossRef] 